\title{
Looks can be deceiving: the deceptive milkcaps (Lactifluus, Russulaceae) exhibit low morphological variance but harbour high genetic diversity
}

Lynn Delgat ${ }^{1 *} \mathbb{D}$, Glen Dierickx ${ }^{1}$, Serge De Wilde ${ }^{1}$, Claudio Angelini ${ }^{2,3}$, Eske De Crop ${ }^{1}$, Ruben De Lange ${ }^{1}$, Roy Halling ${ }^{4}$, Cathrin Manz ${ }^{5}$, Jorinde Nuytinck ${ }^{6}$ and Annemieke Verbeken ${ }^{1}$

\begin{abstract}
The ectomycorrhizal genus Lactifluus is known to contain many species complexes, consisting of morphologically very similar species, which can be considered cryptic or pseudocryptic. In this paper, a thorough molecular study is performed of the clade around Lactifluus deceptivus (originally described by Peck from North America) or the deceptive milkcaps. Even though most collections were identified as $L$. deceptivus, the clade is shown to contain at least 15 species, distributed across Asia and America, indicating that the L. deceptivus clade represents a species complex. These species are morphologically very similar and are characterized by a tomentose pileus with thinwalled hyphae and a velvety stipe with thick-walled hyphae. An ITS1 sequence was obtained through Illumina sequencing for the lectotype of $L$. deceptivus, dating from 1885, revealing which clade represents the true $L$. deceptivus. In addition, it is shown that three other described species also belong to the L. deceptivus clade: $L$. arcuatus, L. caeruleitinctus and L. mordax, and molecularly confirmed that L. tomentoso-marginatus represents a synonym of L. deceptivus. Furthermore, two new Neotropical species are described: Lactifluus hallingii and $L$. domingensis.
\end{abstract}

Keywords: Basidiomycota, Russulales, Lactifluus sect. Albati, Taxonomy, Phylogeny, New taxa

\section{INTRODUCTION}

Lactifluus is a genus of ectomycorrhizal fungi which has its main distribution in the tropics. More than in Lactarius, the genus in which Lactifluus representatives used to be included (Buyck et al. 2008), it is known for its high molecular diversity, with many species complexes occurring throughout the genus (Stubbe 2012; Van de Putte 2012; De Crop 2016). These species complexes consist of several closely related species, with limited morphological variability, making them hard to distinguish from each other.

A good example of such species complexes can be found in Lactifluus section Albati. Species in this section are

\footnotetext{
* Correspondence: lynn.delgat@ugent.be

${ }^{1}$ Department of Biology, Research group Mycology, Ghent University, K.L. Ledeganckstraat 35, 9000 Ghent, Belgium

Full list of author information is available at the end of the article
}

characterized by large white basidiocarps, a velutinous cap, an acrid taste of the context, the presence of macrocystidia and a pileipellis consisting of hyphae, without isodiametric cells. This section was first thought to contain only temperate representatives, with species known from Europe and North America. More recently, some Asian species belonging to this section were discovered, expanding its known distribution across the Northern hemisphere (Wen and Ying 2005; Le et al. 2007b).

The section contains two distinct clades: one with $L$. vellereus, and another with $L$. deceptivus. The $L$. vellereus clade contains the European $L$. vellereus and $L$. bertillonii, the North American L. subvellereus and the Asian L. pilosus and L. puberulus, in addition to a myriad of names at the variety level. In contrast, $L$. deceptivus is described from North America. The also North American L. tomentoso-marginatus was synonymized with $L$. deceptivus based on morphological study of the 
type specimens (Montoya and Bandala 2005). However, molecular data suggested that specimens identified as $L$. deceptivus represented several species, and a detailed molecular study is imperative to resolve the species boundaries in this complex. Therefore, a phylogeny based on multiple loci of the $L$. deceptivus clade was constructed in this paper, including samples from different biogeographic regions.

\section{MATERIAL AND METHODS}

\section{Sampling}

Samples were included from sampling expeditions to the United States of America (2005), Canada (2007), Vietnam (2011), Dominican Republic (2016-2017) and Panama (2018). In addition, loans were requested from the NY, NYS, FLAS and MICH herbaria. Type specimens of described species that (could) belong to L. sect. Albati were requested, but of these the type of $L$. caeruleitinctus was in too poor condition for sequencing. For $L$. deceptivus, no type was designated in the original description. However, Hesler and Smith (1979) indirectly designated a lectotype, and this collection, in addition to five other collections mentioned in the studied material were requested.

\section{Morphological analysis}

Macroscopic characters were observed from fresh material with colour codes referring to Kornerup and Wanscher (1978). Microscopic characters were observed from dried material. Basidiospores were mounted in Melzer's reagent and hymenium, pileipellis and stipitipellis were studied in Congo red in L4. The basidiospore measurements (i.e. length, width and $\mathrm{Q}=$ quotient of length and width) are given as $\left[\mathrm{Av}_{\mathrm{a}}-2 \times \mathrm{SD}_{\mathrm{a}}\right]-A v_{a}-A v_{b}-\left[\mathrm{Av}_{\mathrm{b}}+2 \times \mathrm{SD}_{\mathrm{b}}\right]$, in which $A v_{a}=$ lowest mean value for the measured specimens, $A v_{b}=$ greatest mean value, $\mathrm{SD}_{\mathrm{a} / \mathrm{b}}=$ standard deviation of the measurements with the lowest and greatest mean value respectively (number of spores measured per specimen $=20$ ). Basidiospores were measured in side view without ornamentation. Measurements of basidia, cystidia and marginal cells are given as $[\mathrm{Av}-2 \times \mathrm{SD}]-A v-[\mathrm{Av}+2 \times$ $\mathrm{SD}$ ], based on minimum 47 measurements per species. Measurements of basidia do not include sterigmata. Line drawings of spores were made based on stacked photographs (Nikon Eclipse Ni-U, stacking software: Extended Depth of Field, Nikon Nis Elements module) 5000× magnified, those of other elements and sections were made with the aid of a drawing tube at magnification 1500x (Olympus cx31 microscope).

\section{Molecular analysis}

DNA was extracted from fresh material preserved in CTAB (Cetyl trimethylammonium bromide) using the CTAB extraction described in Nuytinck and Verbeken
(2003). A modified CTAB protocol (Tel-Zur et al. 1999; mod. by Agentschap Plantentuin Meise) was used for dried collections. PCR amplification protocols follow Le et al. (2007a). Two nuclear markers were amplified: (1) the internal transcribed spacer region of ribosomal DNA (ITS), comprising the ITS1 and ITS2 spacer regions and the ribosomal gene 5.8S, using primers ITS1F and ITS4, in addition to primers ITS5, ITS2 and 58SF for problematic material (White et al. 1990; Gardes and Bruns 1993; Tedersoo et al. 2013), and (2) the region between the conserved domains 6 and 7 of the second largest subunit of the RNA polymerase II (RPB2), using primers bRPB26F and fRPB2-7cR (Liu et al. 1999; Matheny 2005).

PCR products were sequenced using an automated ABI 3730 XL capillary sequencer (Life Technology) at Macrogen. Forward and reverse sequences were assembled into contigs and edited with Sequencher v5.0 (Gene Codes Corporation, Ann Arbor, MI, U.S.A.) or BioloMICS (BioAware SA NV).

For the 134-year-old type specimen of $L$. deceptivus, Illumina MiSeq sequencing was chosen as an alternative to conventional Sanger sequencing to overcome the high fragmentation of the ancient DNA and the occurrence of non-target DNA from fungal contaminants. Also, type specimens of $L$. mordax and $L$. tomentoso-marginatus were sequenced with this method. Amplification of the ITS1 region was carried out using a two-step PCR process. In the first PCR, universal ITS1-F/ITS2 primers extended with Nextera $^{\text {m }}{ }^{\text {tails }}$ (Illumina) were used following the same settings as detailed in Le et al. (2007a). After a DNA quantity and quality check, the PCR product was cleaned up with the NucleoMag NGS Clean-up and Size Select kit (Machery-Nagel). In the second PCR, a Nextera $^{\text {Tm }}$ XT label (Illumina) was added to the amplicon under the following conditions: $3 \mu \mathrm{L}$ of template DNA, $1 \mu \mathrm{L}$ of each primer $(10 \mathrm{pmol} / \mu \mathrm{L})$, and $15 \mu \mathrm{L}$ of Master Mix for a final volume of $20 \mu \mathrm{L}$. Amplification conditions were: $95^{\circ} \mathrm{C}$ for $10 \mathrm{~min}, 8$ cycles of $30 \mathrm{~s}$ at $95^{\circ} \mathrm{C}, 60 \mathrm{~s}$ at $55^{\circ} \mathrm{C}$ and $30 \mathrm{~s}$ at $72{ }^{\circ} \mathrm{C}$, followed by $7 \mathrm{~min}$ at $72{ }^{\circ} \mathrm{C}$. After quantification and clean-up, the sample was sent to BaseClear (Leiden, the Netherlands) for paired-end sequencing using the Illumina MiSeq technology $(2 \times 300 \mathrm{bp})$ amongst a batch of other amplicons with different Nextera ${ }^{\text {Tw }}$ labels.

The Illumina sequence reads were processed using the Naturalis Galaxy v.19.01 instance. The reads were demultiplexed on their unique tag to isolate the reads from specific specimens. R1 and R2 reads from pairedend sequencing were merged with FLASH (Magoc and Salzberg, 2011) with the minimum overlap size set at $100 \mathrm{bp}$. Reads shorter than $250 \mathrm{bp}$ or with more than 8 consecutive N's or a Phred score lower than 28 were discarded and primers were trimmed with Cutadapt (Martin 2011). After a quality control step with 
Table 1 Specimens and GenBank accession numbers of DNA sequences used in the molecular analyses

\begin{tabular}{|c|c|c|c|c|}
\hline Species & Number & Fungarium & ITS & RPB2 \\
\hline Amylostereum laevigatum & CBS 623.84 & CBS & AY781246 & AY218469 \\
\hline Auriscalpium vulgare & PBM 944 & WTU & DQ911613 & AY218472 \\
\hline Bondarzewia montana & AFTOL 452 & DAOM & DQ200923 & AY218474 \\
\hline Echinodontium tinctorium & AFTOL 455 & DAOM & AY854088 & AY218482 \\
\hline Heterobasidion annosum & AFTOL 470 & DAOM & DQ206988 & AH013701 \\
\hline Lactarius fuliginosus & MTB 97-24 & GENT & JQ446111 & JQ446240 \\
\hline Lactarius hatsudake & FH 12-052 & GENT & KR364085 & KR364285 \\
\hline Lactarius leoninus & DS 07-454 & GENT & KF220055 & JN375592 \\
\hline Lactarius miniatescens & AV 11-177 & GENT & KR364059 & KR364315 \\
\hline Lactarius olympianus & ED 08-018 & GENT & KR364089 & KR364320 \\
\hline Lactarius pseudodeceptivus & Smith 71,932 & $\mathrm{MICH}$ & MK931348 & - \\
\hline Lactarius pseudodeceptivus & Smith 29,178 & $\mathrm{MICH}$ & MK931349 & - \\
\hline Lactarius pseudodeceptivus & Smith 89,282 & $\mathrm{MICH}$ & MK931350 & - \\
\hline Lactarius scrobiculatus & JN 2001-058 & GENT & KF432968 & KR364344 \\
\hline Lactarius tenellus & ADK 3598 & GENT & KF133280 & KF133345 \\
\hline Lactifluus acrissimus & EDC 11-112 & GENT & KR364041 & KR364254 \\
\hline Lactifluus allardii & JN 2004-008 & GENT & KF220016 & KF220217 \\
\hline Lactifluus arcuatus & FLAS-F-16366 & FLAS & MK931344 & - \\
\hline Lactifluus arcuatus & FLAS-F-60197 & FLAS & MF153025 & MK937138 \\
\hline Lactifluus aurantiifolius & AV 94-063 & GENT & KR364017 & - \\
\hline Lactifluus bertillonii & JN 2012-016 & GENT & KR364087 & KR364261 \\
\hline Lactifluus brachystegiae & AV 99-002 & GENT & KR364018 & KR364262 \\
\hline Lactifluus caeruleitinctus & FLAS-F-59238 & FLAS & MK931345 & - \\
\hline Lactifluus clarkeae & MN 2004002 & L & KR364011 & KR364268 \\
\hline Lactifluus cocosmus & ADK 4462 & GENT & KR364013 & KR364269 \\
\hline Lactifluus deceptivus & AV 05-275 & GENT & MK931336 & - \\
\hline Lactifluus deceptivus & Smith 84,511 & $\mathrm{MICH}$ & MK931351 & - \\
\hline Lactifluus deceptivus & PC BB2004-259 & PC & EU598200 & - \\
\hline Lactifluus deceptivus & NYS-F-000959 & NYS & MN251093 & - \\
\hline Lactifluus densifolius & AV 11-111 & GENT & KR364057 & KR364273 \\
\hline Lactifluus domingensis & ANGE542 & $J B S D$ & MK931339 & MK937130 \\
\hline Lactifluus domingensis & ANGE1035 & $J B S D$ & MK931340 & MK937131 \\
\hline Lactifluus domingensis & ANGE838 & $J B S D$ & MK931341 & MK937132 \\
\hline Lactifluus domingensis & ANGE837 & $J B S D$ & MK931342 & MK937133 \\
\hline Lactifluus edulis & FN 05-628 & GENT & KR364020 & KR364275 \\
\hline Lactifluus foetens & ADK 3688 & MEISE & KR364022 & KR364278 \\
\hline Lactifluus gerardii & AV 05-375 & GENT & GU258254 & GU258353 \\
\hline Lactifluus gymnocarpus & EDC 12-047 & GENT & KR364065 & KR364282 \\
\hline Lactifluus hallingii & FH 18-077 & GENT & MK931338 & MK937129 \\
\hline Lactifluus hallingii & A. E. Franco-Molano 523 & NY & MK931330 & - \\
\hline Lactifluus hallingii & A. E. Franco-Molano 555 & NY & MK931331 & - \\
\hline Lactifluus hallingii & A. E. Franco-Molano 756 & NY & MK931332 & - \\
\hline Lactifluus hallingii & R. E. Halling 4977 & NY & MK931343 & - \\
\hline Lactifluus hallingii & R. E. Halling 7938 & NY & MK931327 & MK937127 \\
\hline
\end{tabular}


Table 1 Specimens and GenBank accession numbers of DNA sequences used in the molecular analyses (Continued)

\begin{tabular}{|c|c|c|c|c|}
\hline Species & Number & Fungarium & ITS & RPB2 \\
\hline Lactifluus hallingii & R. E. Halling 7993 & NY & MK931333 & MK937128 \\
\hline Lactifluus hallingii & NVE 520 & ANDES & KF937338 & - \\
\hline Lactifluus hallingii & NVE 401 & ANDES & KF937337 & - \\
\hline Lactifluus hallingii & NVE 538 & ANDES & KF937339 & - \\
\hline Lactifluus heimii & EDC 11-082 & GENT & KR364040 & KR364286 \\
\hline Lactifluus luteolus & AV 05-253 & GENT & KR364016 & KJ210067 \\
\hline Lactifluus madagascariensis & BB 99-409 & PC & AY606977 & DQ421914 \\
\hline Lactifluus mordax & FLAS-F-52759 & FLAS & MK931346 & - \\
\hline Lactifluus mordax & FLAS-F-61658 & FLAS & MH212033 & MK937139 \\
\hline Lactifluus mordax & HDT 1570 & $\mathrm{MICH}$ & MN251096 & - \\
\hline Lactifluus multiceps & TH 9154A & BRG, DUKE & JN168731 & - \\
\hline Lactifluus oedematopus & KVP 12-001 & GENT & KR364100 & KR364319 \\
\hline Lactifluus pegleri & PAM-Mart12-91 & LIP & KP691416 & KP691433 \\
\hline Lactifluus phlebonemus & EDC 12-023 & GENT & KR364062 & KR364322 \\
\hline Lactifluus pilosus & LTH 205 & GENT & KR364006 & KR364323 \\
\hline Lactifluus Piperati & HKAS J7008 & HKAS & KR364108 & KR364309 \\
\hline Lactifluus piperatus & 2001081968 & GENT & KF220119 & KF241842 \\
\hline Lactifluus pseudogymnocarpus & AV 05-085 & GENT & KR364012 & KR364329 \\
\hline Lactifluus putidus & PAM/Mart 11-013 & LIP & KP691413 & KP691431 \\
\hline Lactifluus ramipilosus & EDC 14-503 & GENT & KR364128 & - \\
\hline Lactifluus robustus & JN 2011-074 & GENT & KR364047 & KR364358 \\
\hline Lactifluus rufomarginatus & ADK 3011 & GENT & KR364034 & KR364336 \\
\hline Lactifluus ruvubuensis & JD 303 & MEISE & KR364009 & KR364310 \\
\hline Lactifluus sp. & PBM 2462 (AFTOL-ID 682) & no data & AY854089 & AY803749 \\
\hline Lactifluus sp. & SDM 037 & $\mathrm{BR}$ & KR364028 & KR364291 \\
\hline Lactifluus sp. & FLAS-F-15973 & FLAS & MK931347 & - \\
\hline Lactifluus sp. & FLAS-F-61618 & FLAS & MH212001 & MK937135 \\
\hline Lactifluus sp. & FLAS-F-61044 & FLAS & $\mathrm{MH} 211710$ & MK937136 \\
\hline Lactifluus sp. & FLAS-F-61657 & FLAS & MH212032 & MK937137 \\
\hline Lactifluus sp. & AV 99-012 & GENT & KR364021 & KR364276 \\
\hline Lactifluus sp. & AV 05-249 & GENT & MK931325 & MK937125 \\
\hline Lactifluus sp. & JN 2007-012 & GENT & MK931326 & MK937134 \\
\hline Lactifluus sp. & AV 04-181 & GENT & MK931328 & DQ421935 \\
\hline Lactifluus sp. & EDC 12-040 & GENT & KR364063 & KR364289 \\
\hline Lactifluus sp. & EDC 12-195 & GENT & KR364071 & KR364301 \\
\hline Lactifluus sp. & JD 907 & GENT & KR364076 & KR364302 \\
\hline Lactifluus sp. & JN 2011-071 & GENT & KR364043 & KR364255 \\
\hline Lactifluus sp. & JN 2011-077 & GENT & KR364044 & KR364256 \\
\hline Lactifluus sp. & AV 05-325 & GENT & MK931329 & - \\
\hline Lactifluus sp. & AV 05-332 & GENT & MK931334 & - \\
\hline Lactifluus sp. & AV 05-350 & GENT & MK931335 & MK937126 \\
\hline Lactifluus sp. & RC/Guy 09-004bis & LIP & KJ786643 & KP691427 \\
\hline Lactifluus sp. & Schaffer 5895 & $\mathrm{MICH}$ & MK931352 & - \\
\hline Lactifluus sp. & Weber 4277 & $\mathrm{MICH}$ & MK931353 & - \\
\hline
\end{tabular}


Table 1 Specimens and GenBank accession numbers of DNA sequences used in the molecular analyses (Continued)

\begin{tabular}{|c|c|c|c|c|}
\hline Species & Number & Fungarium & ITS & RPB2 \\
\hline Lactifluus sp. & Ammirati 2392 & $\mathrm{MICH}$ & MK931354 & - \\
\hline Lactifluus sp. & Ruth Mc Vaugh 1292 & $\mathrm{MICH}$ & MK931355 & - \\
\hline Lactifluus sp. & G3264 & PC & KJ786706 & KP691435 \\
\hline Lactifluus sp. & TENN 065854 & TENN & KR364101 & KR364271 \\
\hline Lactifluus sp. & NVE 396 & ANDES & KF937340 & - \\
\hline Lactifluus sp. & ASM 13521 & EIU & MK931337 & - \\
\hline Lactifluus sp. & 2836 & No data & KJ705226 & - \\
\hline Lactifluus sp. & 2225-QFB-25948 & No data & KJ705225 & - \\
\hline Lactifluus subkigomaensis & EDC 11-159 & GENT & KR364050 & KR364295 \\
\hline Lactifluus subvellereus & AV 05-210 & GENT & KR364010 & KR364347 \\
\hline Lactifluus tomentoso-marginatus & MICH 11224 & $\mathrm{MICH}$ & MN251094 & - \\
\hline Lactifluus tomentoso-marginatus & MICH 37937 & $\mathrm{MICH}$ & MN251095 & - \\
\hline Lactifluus urens & EDC 14-032 & GENT & KR364124 & KR364353 \\
\hline Lactifluus vellereus & ATHU-M 8077 & ATHU-M & KR364106 & KR364354 \\
\hline Lactifluus venezuelanus & RC/Guad11-017 & LIP & KP691411 & KР691429 \\
\hline Lactifluus volemoides & MH 201187 & GENT & KR364098 & KR364363 \\
\hline Lactifluus xerampelinus & MH 201176 & GENT & KR364099 & KR364364 \\
\hline Multifurca furcata & R. E. Halling 7804 & NY & DQ421995 & DQ421928 \\
\hline Multifurca ochricompacta & BB 02-107 & PC & DQ421984 & DQ421940 \\
\hline Multifurca sp. & xp2-20,120,922-01 & GENT & KR364125 & - \\
\hline Multifurca stenophylla & JET956 & MEL & JX266631 & - \\
\hline Multifurca zonaria & FH 12-009 & GENT & KR364083 & KR364365 \\
\hline Russula chloroides/delica & FH 12-272 & GENT & KF432955 & KR364340 \\
\hline Russula cyanoxantha & FH 12-201 & GENT & KR364093 & KR364341 \\
\hline Russula gracillima & FH 12-264 & GENT & KR364094 & KR364342 \\
\hline Russula khanchanjungae & AV-KD-KVP 09-106 & GENT & KR364129 & JN375607 \\
\hline Russula sp. & EDC 12-061 & GENT & KR364072 & KR364338 \\
\hline Russula sp. & EDC 12-063 & GENT & KR364073 & KR364339 \\
\hline Stereum hirsutum & AFTOL 492 & No data & AY854063 & AY218520 \\
\hline Vararia abortiphysa & CBS 630.81 & CBS & KR364005 & KR364266 \\
\hline
\end{tabular}

PRINSEQ (Schmieder and Edwards 2011), the sequences were dereplicated, sorted by size and clustered in zeroradius OTU's with the UNOISE algorithm (Edgar and Flyvbjerg 2015; Edgar 2016) to denoise the amplicon reads. Chimera sequences were removed with the VSEARCH UCHIME algorithm (Edgar et al. 2011). Each zero-radius OTU was then taxonomically assigned by using a BLASTN search (Altschul et al. 1997) against the UNITE and GenBank databases. An OTU abundance table was created and combined with the taxonomic assignments.

The dataset was supplemented with closely related sequences retrieved from GenBank and worldwide reference sequences from De Crop et al. (2017) (Table 1). Metadata of collections in the $L$. deceptivus complex are given in Table 2. Sequences were aligned online in the multiple sequence alignment program MAFFT v7 (Katoh and Toh 2008), using the E-INS-I strategy. Trailing ends were trimmed and the alignment was manually edited where needed in Mega 6 (Tamura et al. 2013). The ITS+LSU alignment was partitioned into partial 18S, ITS1, 5.8S, ITS2 and partial 28S. The RPB2 alignment was partitioned into the intron and the first, second and third codon positions of the exon. PartitionFinder was used to find the appropriate partitioning scheme (Lanfear et al. 2017). Maximum likelihood (ML) analyses, using RAxML v8.0.24 (Stamatakis 2014), were combined with the Rapid Bootstrapping algorithm with 1000 replicates under the GTRCAT option (Stamatakis et al. 2008). There was no supported conflict between the separate gene trees, so they were concatenated. The concatenated alignment can be obtained from the first author or TreeBASE (ID 
Table 2 Metadata of collections in the L. deceptivus complex

\begin{tabular}{|c|c|c|c|c|}
\hline Number & Collection date & Country & Locality & Collector \\
\hline A. E. Franco-Molano 523 & 1990 & Colombia & $\begin{array}{l}\text { Antioquia, Mun. Santa Rosa de Osos, } \\
\text { Vereda El Chaquiro, finca La Española }\end{array}$ & A. E. Franco-Molano \\
\hline A. E. Franco-Molano 555 & 1991 & Colombia & $\begin{array}{l}\text { Antioquia, Mun. San Pedro, } \\
\text { Vereda La Pulgarina }\end{array}$ & A. E. Franco-Molano \\
\hline A. E. Franco-Molano 756 & 1991 & Colombia & $\begin{array}{l}\text { Antioquia, Mun. Santa Rosa de Osos, } \\
\text { Corregimiento de Aragón, vereda El Quince. } \\
\text { Finca San Bernardo. }\end{array}$ & A. E. Franco-Molano \\
\hline Ammirati 2392 & 22/08/1968 & United States & Michigan, Marquette, Yellow Dog Pine Plains & J. F. Ammirati \\
\hline ANGE1035 & 18/12/2017 & Dominican Republic & Jarabacoa & C. Angelini \\
\hline ANGE542 & $10 / 01 / 2016$ & Dominican Republic & Jarabacoa & C. Angelini \\
\hline ANGE837 & $07 / 12 / 2016$ & Dominican Republic & Jarabacoa & C. Angelini \\
\hline ANGE838 & $08 / 12 / 2016$ & Dominican Republic & Jarabacoa & C. Angelini \\
\hline ASM 13521 & $13 / 08 / 2011$ & United States & $\begin{array}{l}\text { New York, Black Pond, Adirondack Park, } \\
\text { Franklin County }\end{array}$ & A. S. Methven \\
\hline AV 04-181 & $13 / 07 / 2004$ & United States & $\begin{array}{l}\text { Tennessee, Sevier County, Cascade Trail in } \\
\text { the Greenbrier section of the Great Smokey } \\
\text { Mountains }\end{array}$ & A. Verbeken \\
\hline AV 05-249 & $12 / 08 / 2005$ & United States & North Carolina, Cataloochee, Caldwell Fork Trail & A. Verbeken \\
\hline AV 05-275 & $12 / 08 / 2005$ & United States & North Carolina, Cataloochee, Rough Fork Trail & A. Verbeken \\
\hline AV 05-325 & $15 / 08 / 2005$ & United States & $\begin{array}{l}\text { North Carolina, Swain County, Round Bottom, } \\
\text { Beech gap Trail }\end{array}$ & A. Verbeken \\
\hline AV 05-332 & $15 / 08 / 2005$ & United States & North Carolina, Swain County, Heintoogard & A. Verbeken \\
\hline AV 05-350 & $17 / 08 / 2005$ & United States & North Carolina, Swain County, Kephart Prong Trail & A. Verbeken \\
\hline FH 18-077 & $19 / 06 / 2018$ & Panama & $\begin{array}{l}\text { Cerro Punta, Montana Azul, Parque Internacional } \\
\text { la Amistad }\end{array}$ & F. Hampe \& C. Manz \\
\hline FLAS-F-15973 & 13/08/1937 & United States & Florida, Alachua, Gainesville & W. A. Murrill \\
\hline FLAS-F-16366 & $15 / 06 / 1938$ & United States & Florida, Alachua, Gainesville & W. A. Murrill \\
\hline FLAS-F-52759 & $25 / 08 / 1981$ & United States & $\begin{array}{l}\text { Florida, Alachua, Gainesville, Newnan's Lake area, } \\
\text { west shore }\end{array}$ & Benny \& Kimbrough \\
\hline FLAS-F-59238 & $04 / 12 / 2004$ & United States & Florida, Okaloosa, Elgin Air Force Base & D. P. Lewis \\
\hline FLAS-F-60197 & 24/10/2016 & United States & $\begin{array}{l}\text { Florida, Putnam, Ordway-Swisher Biological Station. } \\
\text { Between Lake Rowan and Lake Barco, near Road } \\
\text { B17 intersection }\end{array}$ & Smith Lab \\
\hline FLAS-F-61044 & 28/06/2017 & United States & $\begin{array}{l}\text { Florida, Putnam, Ordway-Swisher Biological Station, } \\
\text { northwest of Ashley Lake }\end{array}$ & D. Borland \& B. Kaminsky \\
\hline FLAS-F-61618 & $16 / 09 / 2017$ & United States & $\begin{array}{l}\text { Florida, Alachua, Owen-Illinois Park, Windsor, Florida, } \\
\text { USA. }\end{array}$ & B. Kaminsky \\
\hline FLAS-F-61657 & 20/09/2017 & United States & $\begin{array}{l}\text { Florida, Putnam, Ordway-Swisher Biological Station, } \\
\text { by D10 road intersection }\end{array}$ & D. Borland \& B. Kaminsky \\
\hline FLAS-F-61658 & 20/09/2017 & United States & $\begin{array}{l}\text { Florida, Putnam, Ordway-Swisher Biological Station, } \\
\text { by D10 road intersection }\end{array}$ & D. Borland \& B. Kaminsky \\
\hline HDT 1570 & $22 / 05 / 1952$ & United States & Texas, Grimes, Navasota & H. D. Thiers \\
\hline JN 2007-012 & $26 / 09 / 2007$ & Canada & $\begin{array}{l}\text { Newfoundland, Avalon Peninsula, Salmonier road (90), } \\
\text { Salmonier National Park }\end{array}$ & J. Nuytinck \\
\hline JN 2011-071 & $16 / 06 / 2011$ & Viet Nam & $\begin{array}{l}\text { Bi Dup Nui Ba National Park, Huyen Lac Duong, } \\
\text { Dalat city, near Tram Kiem Lam Giang Ly }\end{array}$ & J. Nuytinck \\
\hline JN 2011-077 & $16 / 06 / 2011$ & Viet Nam & $\begin{array}{l}\text { Bi Dup Nui Ba National Park, Huyen Lac Duong, } \\
\text { Dalat city, near Tram Kiem Lam Giang Ly }\end{array}$ & J. Nuytinck \\
\hline MICH 11224 & $27 / 08 / 1973$ & United States & Michigan, Oscoda, Perry Creek, Mio & C. Nimke \\
\hline MICH 37937 & 22/09/1975 & United States & Michigan, Washtenaw, Winnewana Lake & A. H. Smith \\
\hline NYS-F-000959 & August & United States & New York, Rensselaer, Sandlake & C. H. Peck \\
\hline
\end{tabular}


Table 2 Metadata of collections in the L. deceptivus complex (Continued)

\begin{tabular}{|c|c|c|c|c|}
\hline Number & Collection date & Country & Locality & Collector \\
\hline R. E. Halling 4977 & 1986 & Colombia & $\begin{array}{l}\text { Antioquia, Mun. Santa Rosa de Osos, } \\
\text { Near Llanos de Cuiva }\end{array}$ & R. E. Halling \\
\hline R. E. Halling 7938 & $26 / 06 / 2000$ & Costa Rica & $\begin{array}{l}\text { San José: Canton Dota, San Gerardo. } \\
\text { Albergue de la Montaña, Savegre, } 5 \text { km SW } \\
\text { of Cerro de la Muerte }\end{array}$ & R. E. Halling \\
\hline R. E. Halling 7993 & 07/08/2000 & Costa Rica & San José: Canton Dota, Jardin, 3,5 km W of Empalme & R. E. Halling \\
\hline Ruth Mc Vaugh 1292 & 21/09/1967 & Mexico & $\begin{array}{l}\text { Oaxaca, } 3-5 \mathrm{~km} \text { E of Ixtlan de Juarez, along } \\
\text { road to Capulalpan }\end{array}$ & R.B. McVaugh \\
\hline Schaffer 5895 & $17 / 08 / 1967$ & Canada & Quebec, Charlevoix, Baie Saint Paul & R. L. Shaffer \\
\hline Smith 84,511 & 22/08/1973 & United States & Michigan & A. H. Smith \\
\hline TENN 065854 & $12 / 08 / 2011$ & United States & $\begin{array}{l}\text { New York, Paul Smith's Franklin, Boreal Life trail, } \\
\text { Walk No.8: Barnum Brook, New England Mycological } \\
\text { Foray }\end{array}$ & S. Rock \\
\hline Weber 4277 & $14 / 09 / 1974$ & United States & Wisconsin & N. S. Weber \\
\hline
\end{tabular}

24889). All analyses were conducted on the CIPRES Science Gateway (Miller et al. 2010).

\section{RESULTS}

Illumina Miseq sequencing was used to sequence the type specimen of $L$. deceptivus collected in 1885 . After library sequencing, merging read pairs and quality control steps for this type specimen, 727 ITS1 sequences were retained that were clustered in 10 zero-radius OTU's. Only one of these belonged to the genus Lactifluus, and this sequence was used in further phylogenetic analysis. Other OTU's represent contaminants, the most abundant being Penicillium. For the type specimens of L. mordax and L. tomentoso-marginatus, 125-271 sequences were retained, clustered in 4-6 zero-radius OTU's, which each contained one sequence related to $L$. deceptivus s. lat.

In total, sequences were obtained for 47 collections belonging to the $L$. deceptivus complex. Of these collections, 36 had been identified based on morphology as $L$. deceptivus (most other collections were not identified to species level). The phylogeny shows that these collections represent at least 15 species (Fig. 1). Most species originate from the Nearctic, but also two Indomalayan and three Neotropical species were found. Only four species were described thusfar, so an additional 11 new species were uncovered by the molecular analysis.

\section{TAXONOMY}

Genus Lactifluus (Pers.) Roussel

Lactifluus subgenus Lactariopsis (Henn.) Verbeken

Lactifluus section Albati (Bataille) Verbeken

Lactifluus domingensis Delgat \& Angelini, sp. nov.

MycoBank MB831084

(Figs. 2 and 3)
Etymology: Refers to the island where the species was found. (Hispaniola previously consisted of Santo Domingo and Saint-Domingue, currently Dominican Republic and Haiti respectively.)

Diagnosis: Differs from clade 5 in the slightly lower average $\mathrm{Q}$ of the basidiospores, the slightly larger basidia, the slightly longer cystidia, the Hispaniolan distribution and the association with Pinus occidentalis.

Type: Dominican Republic: La Vega province: Jarabacoa, mixed wood mostly with Pinus occidentalis, 8 Dec.2016, C. Angelini ANGE838 (JBSD 130755 - holotype JBSD; GENT - isoptype).

Description: Pileus 35-100 mm diam, compact, at first convex and umbilicate, becoming flat, with depressed centre that becomes deeply depressed with maturity; surface at first bald, but soon roughening, becoming torn into patches or scales, dry to sticky at the centre; margin at first involute and clothed with a soft or cottony tomentum, then spreading or becoming elevated and more or less fibrillose, with a hand-lens loosely arranged brown pigmented hairs are visible; surface whitish at first, soon discolouring tan and brownish. Stipe 17-50 × 10-20 mm, rather short (compared to the diameter of the cap), usually tapering to base; surface dry, irregularly rugged, slightly velvety towards the base, whitish, discolouring brownish or tan; context solid. Lamellae adnate or slightly decurrent, with lamellulae of various length, rather broad, to $5 \mathrm{~mm}$ wide, subdistant, occasionally forking, whitish or pale yellowish, becoming cream coloured and finally dingy tan, usually staining and discolouring brownish; edge entire and concolourous. Context firm, white, unchanging when cut; smell pungent at maturity; taste strongly acrid. LATEX white; unchanging; often staining brownish. Chemical reactions: Cap surface reddish with $\mathrm{KOH}$. 


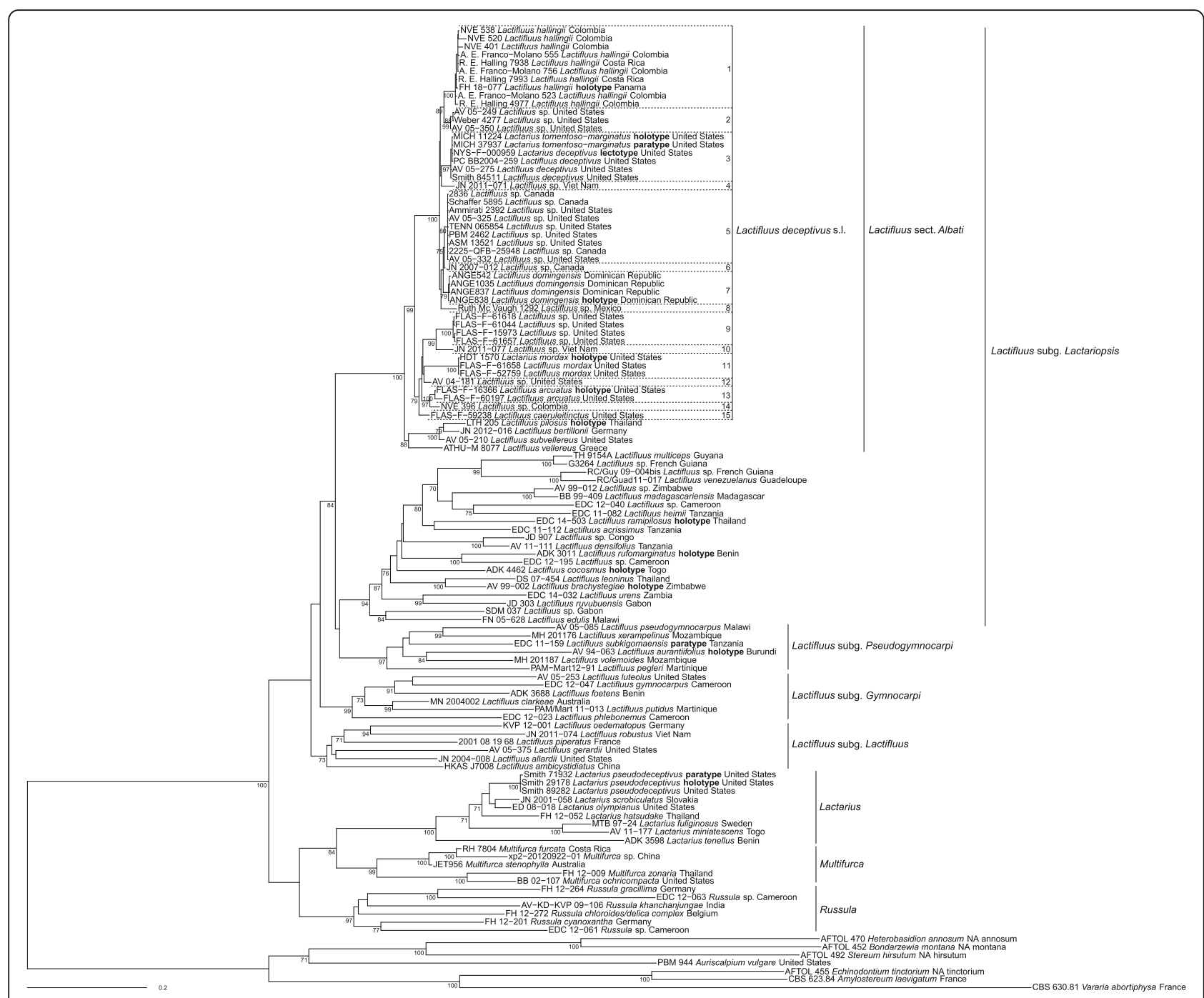

Fig. 1 Maximum Likelihood tree based on concatenated ITS and RPB2 sequence data. Maximum Likelihood bootstrap values $>70$ are shown

Basidiospores broadly ellipsoid to ellipsoid, 8-8.9-10.1$11.5 \times 6.3-7-7.7-8.7 \mu \mathrm{m}(\mathrm{Q}=1.15-1.25-1.31-1.50)$, ornamentation to $1.7 \mu \mathrm{m}$ high, consisting of isolated conical warts; plage inamyloid, rarely centrally weakly amyloid. $\mathrm{Ba}$ sidia (42-)43-53-63.5 × 9.5-12.5-15.5 $\mu \mathrm{m}$, subclavate, majority 4-spored, some 2- or 1-spored. Pleuromacrocystidia 35-62.5-90(-101) ×5-7-9 $\mu \mathrm{m}$, abundant, cylindrical with tapering, mucronate or moniliform apex, sometimes branching, thin-walled. Pleuropseudocystidia $3.5-9 \mu \mathrm{m}$ diam, not to slightly emergent. Sterile elements 27-37$46.5 \times 4-5-6.5 \mu \mathrm{m}$, cylindrical, septate, with rounded apex. Lamellar edge sterile; marginal cells 9.5-23.5-38(40) $\times$ 4.59.5-14(-16) $\mu \mathrm{m}$, cylindrical to clavate, sometimes septate. Hymenophoral trama mixed, with hyphae, lactifers and sphaerocytes. Pileipellis a very loosely arranged cutis to trichoderm, up to $200 \mu \mathrm{m}$ thick, composed of very broad $(8-20$, sometimes $30 \mu \mathrm{m}$ diam.) and slightly thick-walled hairs, that are periclinally to anticlinally arranged and have a pale brown pigmentation. Some branchings and bulges of the hyphae are present. Stipitipellis a loosely arranged lamprotrichoderm on top of a layer of globose cells, up to $150 \mu \mathrm{m}$ thick; terminal elements thick-walled, 50-150 $\times 5$ $8 \mu \mathrm{m}$, usually straight and hair-shaped and with tapering apex, periclinally to anticlinally arranged.

Ecology: Found in montane forests with Pinus occidentalis.

Distribution: Only known from the Dominican Republic, on the island of Hispaniola.

Remarks: Several hosts have been reported for Lactifluus deceptivus s. lat., such as Pinus, Tsuga, and Quercus species. In the Dominican Republic, where this new species 

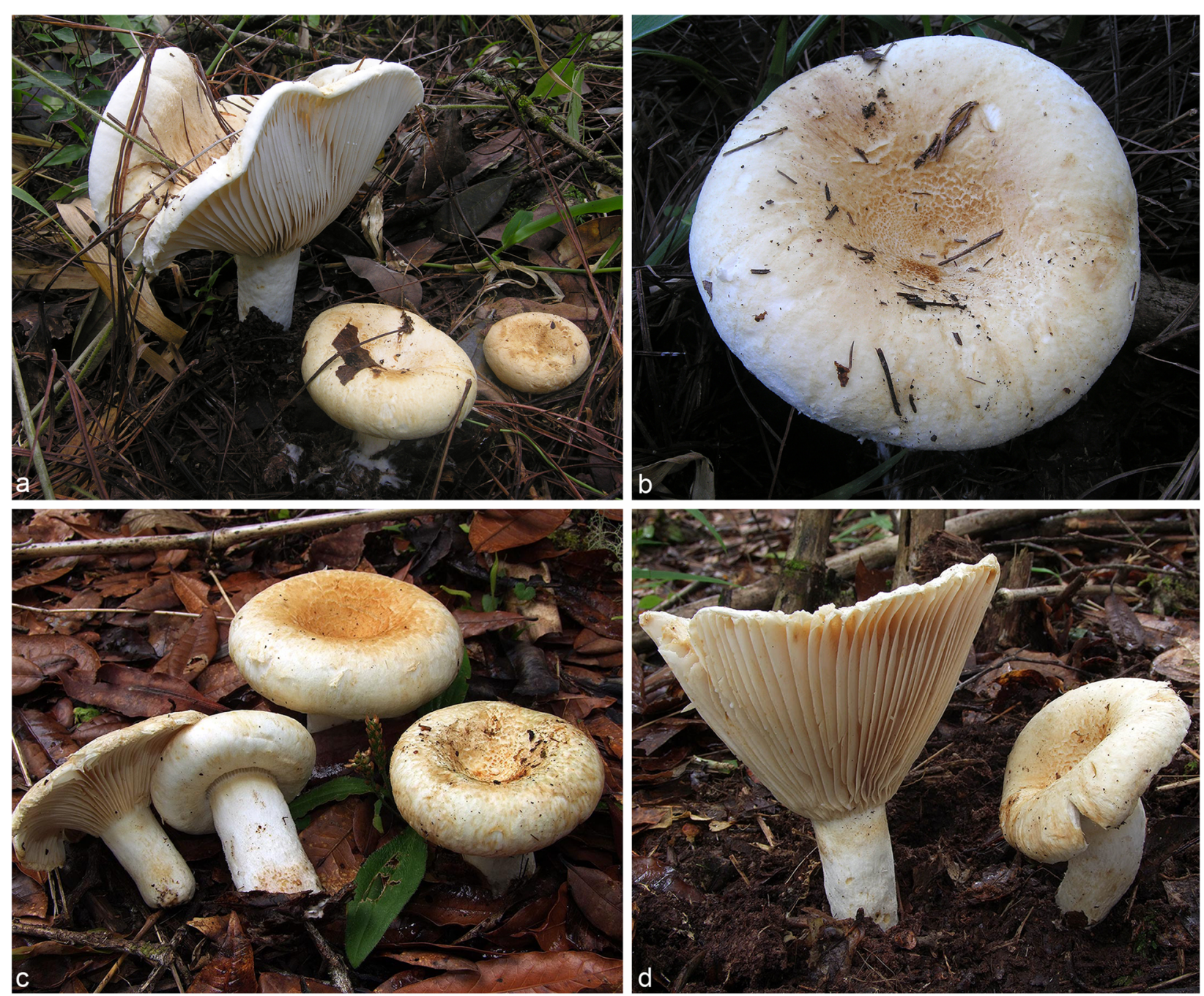

Fig. 2 Basidiomes. a Lactifluus domingensis (ANGE838-holotype). b Lactifluus domingensis (ANGE837). c-d Lactifluus hallingii (FH 18-077-holotype)

was found, no Fagaceae occur. There are two species of pines on the island: the endemic Pinus occidentalis (in the central Cordillera) and the introduced P. caribaea (in the northern Cordillera). Lactifluus domingensis has been found exclusively with the endemic $P$. occidentalis and never with the introduced $P$. caribaea. This association with $P$. occidentalis, and therefore Hispaniolan distribution, is probably a unique feature of the species. So far, no other Lactifluus species are known from this island. Aside from its distinctive distribution, L. domingensis bears great resemblance to the other species of the Lactifluus deceptivus species complex, both macro- and microscopically. The phylogeny shows that $L$. domingensis is most closely related to a single collection from Canada (clade 6) and a clade with a northern North American distribution: clade 5 (Fig. 1) (although unsupported, but strongly supported in the separate ITS phylogeny).
Clade 5 differs from $L$. domingensis by the slightly higher average Q (1.22-1.34-1.35-1.47), the slightly smaller basidia $(24-43-62 \times 3.5-11.5-19 \mu \mathrm{m})$ and the slightly shorter cystidia $(44-54-63.5 \times 4-7.5-10.5 \mu \mathrm{m})$. Compared to the two described species from Florida, $L$. arcuatus has distinctly smaller spores $(4-6 \mu \mathrm{m}$ long), and L. caeruleitinctus has blue tinges in the stipe which are lacking in $L$. domingensis. Lastly, $L$. hallingii also has a Central American distribution, but this species was found with Quercus species. In addition, there are some subtle microscopic differences: $L$. hallingii has slightly lower spore ornamentation (up to $1.5 \mu \mathrm{m}$ ), somewhat longer basidia $(45.5-63.5-81.5(-83) \times 10-13-$ $16 \mu \mathrm{m}$ ), somewhat differently shaped macrocystidia (i.e. more rarely a mucronate or moniliform apex, more often with a rounded or tapering apex) and an irregular cutis as a pileipellis. 


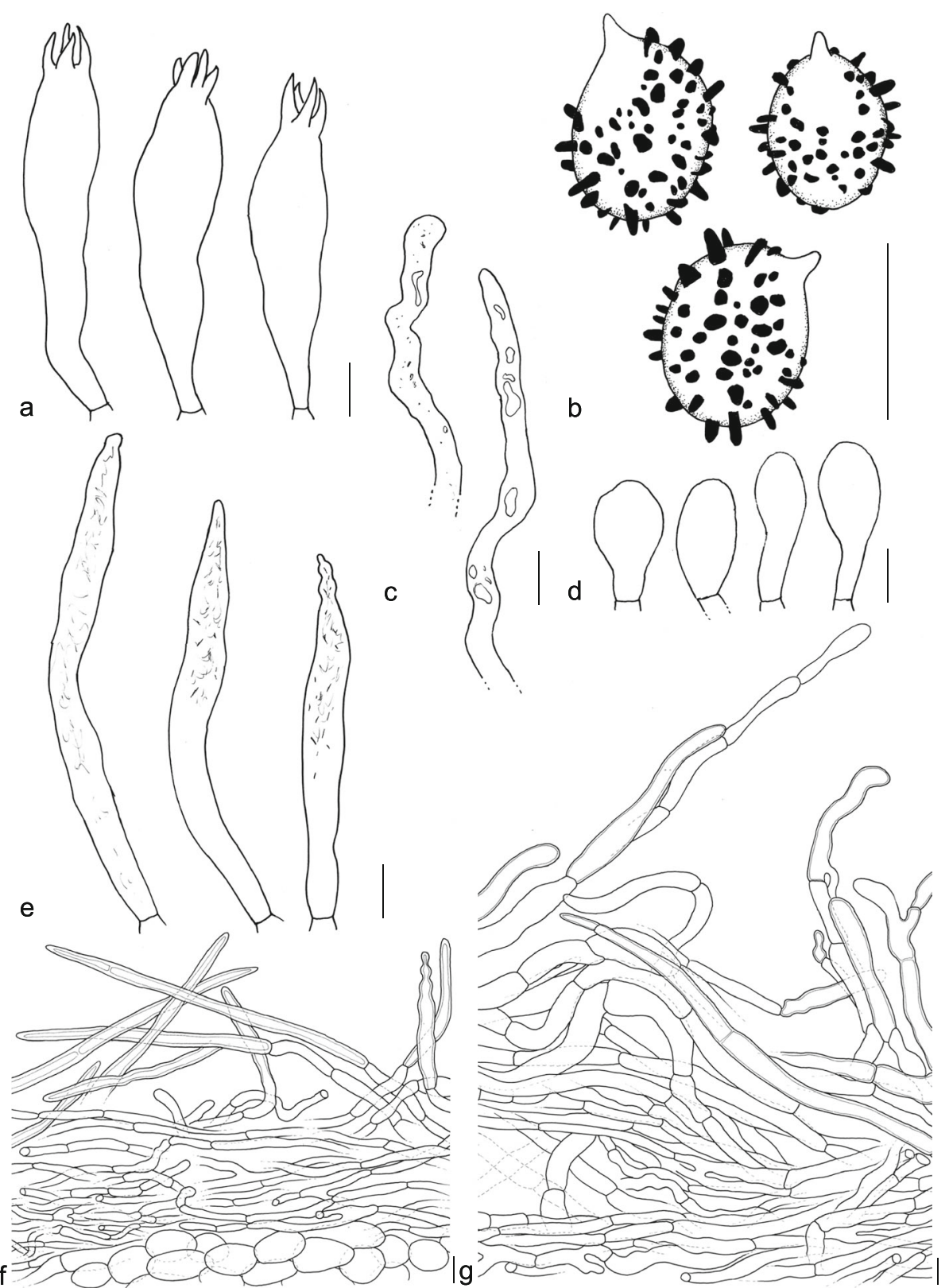

Fig. 3 Lactifluus domingensis (ANGE 542, ANGE 837, ANGE838). a Basidia. b Basidiospores. c Pseudocystidia. d Marginal cells. e Macrocystidia. f Section through the stipitipellis. $\mathbf{g}$ Section through the pileipellis. Bars $=10 \mu \mathrm{m}$

Other specimens examined: Dominican Republic: La Vega province: Jarabacoa: mixed woods mostly with Pinus occidentalis, on soil, 10 Jan./2016, C. Angelini ANGE542 (JBSD 130756); ibid., 7 Dec. 2016, C. Angelini ANGE837 (JBSD 130757); ibid., 18 Dec. 2017, C. Angelini ANGE1035 (JBSD 130758).

Lactifluus hallingii Delgat \& De Wilde, sp. nov.

MycoBank MB831085
(Figs. 2 and 4)

Etymology: Refers to mycologist Roy E. Halling, who made several collections of this species.

Diagnosis: Differs from clade 2 in the larger basidia, the longer macrocystidia and the Neotropical distribution.

Type: Panama: Cerro Punta, Montana Azul, Parque Internacional la Amistad $\left(8.894361^{\circ}\right.$; $-82.581956^{\circ}$, alt. 2338 m), soil with Quercus sp., 19 June 2018, F. Hampe 

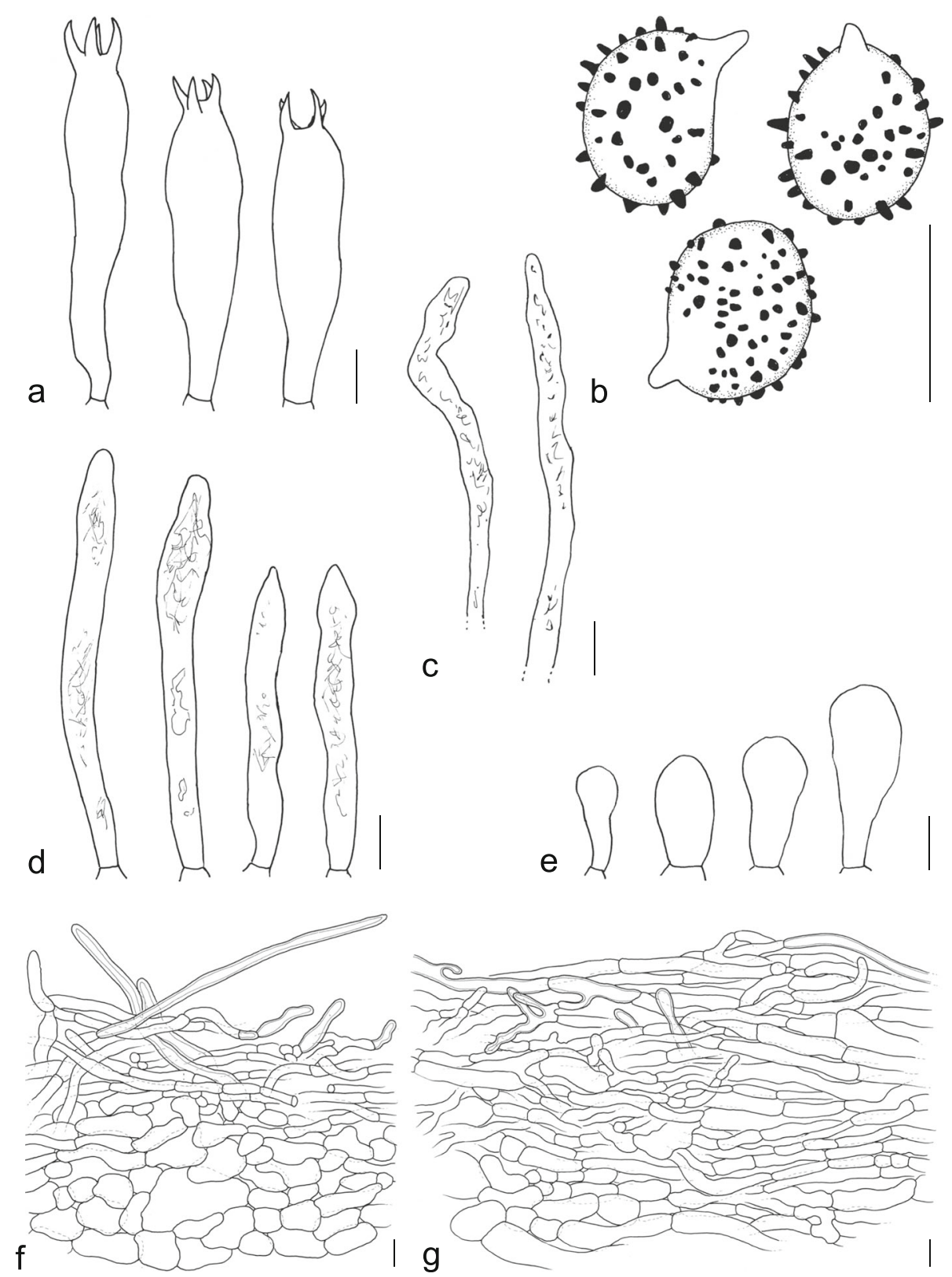

Fig. 4 Lactifluus hallingii (AEF 555, AEF 756, FH 18-077, REH 7993). a Basidia. b Basidiospores. c Pseudocystidia. d Macrocystidia. e Marginal cells. f Section through the stipitipellis. $\mathbf{g}$ Section through the pileipellis. Bars $=10 \mu \mathrm{m}$

\& C. Manz FH 18-077 (GENT - holotype; UCH 10505 - isotype)

Description: Pileus 40-165(-240) mm diam, infundibuliform; margin strongly involute when young; surface dry, matted tomentose at first, eventually fibrillose to squamulose at disc, with cottony roll of tissue at margin when young, later appressed fibrillose to tomentose, cream or pale orange (4A2-4A5, 5A3) at first, then browner near brownish orange (6C6) at disc and paler (whitish) towards the margin. STIPE 30-90 $\times 11-35 \mathrm{~mm}$, cylindrical, sometimes curved; surface white, staining brownish (4A3-4) where injured, dry, tomentose to pubescent. Lamellae adnate to subdecurrent to decurrent, up to $6 \mathrm{~mm}$ wide, subdistant, occasionally forking, white to cream (4A2-3); edge entire and concolourous. Context firm, white, unchanging when cut; smell fruity and cheesy; taste very acrid. Latex scarce to abundant, white, staining tissues pinkish to eventually brownish; taste very acrid. Chemical reactions: context green blue 
with guaiac, orange with $\mathrm{FeSO}_{4}$; cap surface reddish cinnamon with $\mathrm{KOH}$.

Basidiospores broadly ellipsoid to ellipsoid, 8.1-9.6$10.4-11.3 \times 6.7-7.4-8.5-9.5 \mu \mathrm{m} \quad(\mathrm{Q}=1.15-1.21-1.32-$ 1.47); ornamentation up to $1.5 \mu \mathrm{m}$ high, consisting of isolated conical warts, sometimes connected by very faint and fine lines; plage inamyloid, rarely centrally amyloid. BASIDIA 45.5-63.5-81.5(-83) × 10-13-16 $\mu \mathrm{m}$, subclavate, 4-spored. Pleuromacrocystidia (45-)4670.5-95.5(-103) × (4-) 4.5-6.5-9(-10) $\mu \mathrm{m}$, abundant, cylindrical with tapering and fusiform apex, thin-walled. Pleuropseudocystidia $2.5-7 \mu \mathrm{m}$ diam, not to slightly emergent. Sterile elements 37-49-62(64) $\times 3-5-7 \mu \mathrm{m}$, cylindrical, septate, with rounded apex. LAMELLAR EDGE sterile; marginal cells $13-23.5-34 \times(5-) 5.5-9.5-13(-$ 13.5) $\mu \mathrm{m}$, cylindrical to clavate, sometimes septate. HyMENOPHORAL TRAMA mixed, with hyphae, lactifers and sphaerocytes. Pileipellis an irregular cutis, to $100 \mu \mathrm{m}$ thick, consisting of loosely interwoven hyphae which are often slightly thick-walled and refringent, about 5$8 \mu \mathrm{m}$ diam, but locally also swollen up to $20(-30) \mu \mathrm{m}$; terminal hyphae with remarkable bulges and branchings often present. Stipitipellis a thin lamprotrichoderm on top of a layer of globose cells; all terminal elements refringent to slightly thick-walled, but some very thick-walled, $15-100 \times 5-8 \mu \mathrm{m}$, cylindrical, with rounded or slightly tapering top; terminal elements anticline to very oblique, sometimes rather periclinally arranged.

Ecology: Found on soil in montane forests with Quercus humboldtii, Q. seemannii, Q. copeyensis, and Quercus sp.

Distribution: Known from Costa Rica, Panama, and Colombia.

Remarks: As Lactifluus domingensis, L. hallingii bears great resemblance to some of the other species from the $L$. deceptivus species complex, both macro- and microscopically. In the phylogeny (Fig. 1), we find that L. hallingii is most closely related to a clade with a North American distribution: clade 2 (Fig. 1). Clade 2 differs from L. hallingii in the smaller basidia (30.5-42.5-54 $\times$ $7.5-11.5-16 \mu \mathrm{m})$ and the shorter macrocystidia (29-52$75 \times 5-9-13.5 \mu \mathrm{m})$. Compared to L. hallingii, the species described from Florida are relatively easily distinguishable: $L$. arcuatus has distinctly smaller spores $(4-6 \mu \mathrm{m}$ long), and L. caeruleitinctus has blue tinges in the stipe which are lacking in L. hallingii. Lactifluus domingensis shares the Neotropical distribution, but that species was found with the endemic Pinus occidentalis on the island of Hispaniola. For microscopic differences between these two species, see the remarks under $L$. domingensis.
Other specimens examined: Colombia: Antioquia: Municipio Santa Rosa de Osos, near Llanos de Cuiva $\left(6.75^{\circ} ;-75.5^{\circ}\right.$, alt. $\left.2500 \mathrm{~m}\right)$, Andean forest, 5 Nov. 1986, R. E. Halling 4977 (NY); vereda El Chaquiro, finca La Española (alt. $2700 \mathrm{~m}$ ), with Quercus humboldtii, 12 June 1990, A. E. Franco-Molano 523 (NY); Municipio de San Pedro, vereda La Pulgarina, with Quercus humboltii, 27 Apr. 1991, A. E. Franco-Molano 555 (NY); Municipio Santa Rosa de Osos, corregimiento de Aragon, vereda El Quince, Finca San Bernardo (alt. 2900 m), 17 June 1991, A. E. Franco-Molano 756 (NY)/

- Costa Rica: San José, Canton Dota, Jardin, 3.5 km W of Empalme $\left(9.7144^{\circ} ;-83.9744^{\circ}\right.$, alt. $\left.2220 \mathrm{~m}\right)$, with Quercus seemannii and Q. copeyensis, 07 Aug. 2000, R. E. Halling $7993(\mathrm{NY})$.

\section{Lactifluus arcuatus (Murrill) Delgat, comb. nov.}

\section{MycoBank MB831087}

Basionym: Lactarius arcuatus Murrill, Mycologia 33: 440 (1941).

Synonym: Lactaria arcuata Murrill, Mycologia 33: 440 (1941); orth. Var.

Remarks: Based on the original description, this species could fit morphologically in $L$. sect. Albati because of the white basidiome, the cottony inrolled margin, and the acrid latex. The placement in this section is confirmed molecularly by the position of the type sequence in the phylogeny (Fig. 1).

Lactifluus caeruleitinctus (Murrill) Delgat, comb. nov.

$$
\text { MycoBank MB831088 }
$$

Basionym: Lactarius caeruleitinctus Murrill, J. Elisha Mitchell Sci. Soc. 55: 368 (1939).

Synonym: Lactaria caeruleitincta Murrill, J. Elisha Mitchell Sci. Soc. 55: 368 (1939); orth. Var.

Remarks: Based on Murrill's notes on the type specimen, this species could fit morphologically in $L$. sect. Albati because of the white basidiome, the acrid taste, and the strongly unpleasant smell while drying. The placement of a collection identified as $L$. caeruleitinctus in $L$. sect. Albati (Fig. 1) further supports the placement of this species in L. sect. Albati.

Lactifluus mordax (Thiers) Delgat, comb. nov.

MycoBank MB832122 
Basionym: Lactarius mordax Thiers, Mycologia 49: 710 (1957).

Remarks: Based on the original description, this species could fit morphologically in $L$. sect. Albati because of the matted-tomentose margin, the very acrid latex, and the cuticular structure of the pileipellis. The placement in this section is confirmed molecularly by the position of the type sequence in the phylogeny (Fig. 1).

\section{DISCUSSION}

A first attempt to find out which clade represents $L$. deceptivus was made by sequencing several collections from the studied material from Hesler \& Smith's description (Hesler and Smith 1979): collections Schaffer 5895, Ammirati 2392, Smith 84,511, and Weber 4277. However, our analysis inferred that these collections represent three different species: clades 2, 3, and 5 (Fig. 1), thus the interpretation of $L$. deceptivus remained elusive. In the phylogeny, there are several clades that have a relatively close distribution to where $L$. deceptivus was described (i.e. New York State): clades 2, 3, 5, and 12. The only microscopic character mentioned in the original description (Peck 1885) is the length of the spores $(8.9-12.7 \mu \mathrm{m})$, so spores were measured for these four clades. Clade 12 has significantly smaller spores (5.9-7$8 \times 4.6-5.3-6.1 \mu \mathrm{m})$, but the other three clades have similar spore sizes (clade 2: 9.6-10.6-10.9-11.9 × 7.5$8.4-8.5-9.5 \mu \mathrm{m} ; \quad$ clade $3: \quad 9.4-10.6-11.8 \times 7.8-8.5-$ $9.3 \mu \mathrm{m}$; clade 5: $9.9-10.7-10.8-11.9 \times 7.4-8-8.6 \mu \mathrm{m})$, so all three clades were considered possible candidates to represent the true $L$. deceptivus.

Lactifluus deceptivus was described by Peck (1885), and Hesler and Smith (1979) designated a lectotype (Peck s.n., NYS-F-000959). Samples this old have both time and conservation related DNA damage, besides exogenous DNA contamination, that makes nucleic acid extraction and amplification challenging (Forin et al. 2018). Therefore, Illumina Miseq sequencing was chosen as an alternative to the conventional Sanger sequencing to overcome these problems for the type specimen of $L$. deceptivus. As expected, due to both the old age and the lack of precautions during the manipulation of specimens throughout the herbarium's long life, contaminants are present in this specimen, and a total of 10 zero-radius ITS1 OTU's were recovered from the sample. One Lactifluus sequence was picked up by the analysis. Phylogenetic analysis shows that this sequence belongs to clade 3, which was indeed considered a possible candidate based on distribution and spore measurements, revealing that this clade represents the true $L$. deceptivus.

Three other described species were found to belong in the complex: $L$. arcuatus and $L$. caeruleitinctus, described from Florida by Murrill (1939, 1941); and $L$. mordax, described from Texas by Thiers (Thiers 1957). Descriptions of Murrill's species are rather concise, but both species have at least a clear character that sets them apart from $L$. deceptivus: $L$. arcuatus has distinctly smaller spores, and $L$. caeruleitinctus displays blue tinges in the stipe. Lactifluus mordax is can be macroscopically distinguished from $L$. deceptivus by the pileus colour, which is not white but yellow to cream, and microscopically by the smaller spores $(7.5-9 \times 6-7 \mu \mathrm{m})$ (Hesler and Smith 1979). A sequence was obtained for the holotypes of $L$. arcuatus and $L$. mordax, as well as a collection identified as L. caeruleitinctus, which shows that these species belong to a subclade (clades 9-15) of the $L$. deceptivus complex which is dominated by species known only from Florida (Fig. 1 ). Since $L$. deceptivus is situated in the other subclade (clades 1-8), these species are relatively more distantly related to $L$. deceptivus, which could explain why they are more easily distinguishable from it. Lactifluus tomentoso-marginatus was previously synonymised with $L$. deceptivus based on a detailed morphological study (Montoya and Bandala 2005), and the phylogeny confirms this synonymy by the position of the holotype in the same clade as the type of L. deceptivus (Fig. 1). However, other collections studied in the paper of Montoya and Bandala, originating from Mexico and initially identified as L. tomentosomarginatus, were also considered to belong to the same species by the authors based on the morphological study. A sequence was obtained for one of these collections, and the phylogeny shows that it represents a distinct clade from L. deceptivus (clade 8, Fig. 1), further demonstrating the difficulty of morphologically delimiting species in this complex.

The Lactifluus deceptivus complex previously exclusively contained species described from the Nearctic. It was shown that species from this complex also occur in Indo-Malaya and the Neotropics, and two new Neotropical species are described. Lactifluus domingensis was found in the Dominican Republic, on the island of Hispaniola, while L. hallingii was found on the mainland, distributed across Costa Rica, Panama and Colombia. For most of the other clades, welldocumented collections are lacking due to the previous perception that $L$. deceptivus represented just a single, easy to recognize species. In addition, many of the clades contain only one or two collections, so to further unravel this complex there is a need for more well-documented collections. Hopefully, $L$. deceptivus s. lat. Will be collected and described in more detail now that it is known to represent several morphologically similar species.

Since species in this complex resemble each other so strongly, they can be considered pseudocryptic species. 
This means that, while at first, they seem indistinguishable, they can be distinguished from each other once the appropriate character(s) is/are considered. This phenomenon is widespread in the genus Lactifluus (e.g. Stubbe et al. 2010; Van de Putte et al. 2010; Van de Putte 2012; De Crop et al. 2014; Van de Putte et al. 2016; Delgat et al. 2017; De Lange et al. 2018). For example, a very similar case to that described in this paper occurs in $L$. sect. Lactifluus: as with $L$. deceptivus, $L$. volemus was thought to be a single, easily recognizable species in Europe, with the same name also being applied on other continents. However, molecular analysis revealed a total of 35 species in this complex (Van de Putte 2012). Without molecular data it is next to impossible to delimit these pseudocryptic species, but once you ascertain which collections group together, morphological, although often subtle, differences may be found to distinguish between the species. Often, these species are relatively recently diverged from each other, as can be observed from the relatively short branch lengths (Fig. 1), and could explain why the morphologies have not diverged much from each other. Despite this limited morphological variability, we find that the Lactifluus deceptivus complex does contain a high diversity of species. The phylogeny (Fig. 1) reveals a total of at least 15 species, distributed across Asia, North and Central America.

Together with the clade around Lactifluus vellereus, another clade that can be considered a species complex, the $L$. deceptivus complex comprises $L$. sect. Albati. In contrast to species from the L. deceptivus clade, species from the $L$. vellereus clade have a lamprotrichoderm structure of the pileipellis with very long hairs (to 250 $300(400) \mu \mathrm{m})$, causing the pileus surface to be extremely velutinous. The clade around $L$. vellereus contains at least 14 species (De Crop 2016; unpubl. results), which brings the total diversity of $L$. sect. Albati to 29 species. Considering that De Crop (2016) reports a total species diversity of 369 Lactifluus species, distributed across 37 clades, averaging ten species per clade, $L$. sect. Albati can be considered a relatively species-rich section. In addition, many of the species in the section are known from only one collection, so it can be expected that the diversity will be even higher.

It is noteworthy that the position of $L$. sect. Albati in L. subg. Lactariopsis is not supported in the phylogeny (Fig. 1). Also in the study of De Crop et al. 2017 this position was not supported in all separate gene phylogenies, which is why this section could be considered as a separate group from the subgenus. However, in order to favour more or less equal sized subgenera, (De Crop et al. (2017)) decided to include this section in L. subg. Lactariopsis. Lactifluus sect. Albati differs from the other sections in $L$. subg.
Lactariopsis by the presence of macropleurocystidia, while true cystidia are lacking in most species of this subgenus. In addition, it is the only section in the subgenus which has temperate representatives.

Considering its name, it might be thought that Lactarius pseudodeceptivus would also belong to the clade around $L$. deceptivus. However, this species belongs in the genus Lactarius, as is confirmed by the placement of sequences of the holotype and paratypes in Lactarius (Fig. 1). There are some similarities with $L$. deceptivus, such as the inrolled cottony-tomentose margin and acrid taste. However, Lactarius pseudodeceptivus can be distinguished from species of the Lactifluus deceptivus complex, notably by the reticulated spore ornamentation and the ixocutis structure of the stipitipellis.

\section{CONCLUSION}

Lactifluus deceptivus was previously thought to be a single, easily recognisable species. However, molecular analysis revealed that Lactifluus deceptivus s. lat. Represents a species complex containing at least 15 species, distributed across Asia and America. Despite the low morphological variability in this complex, it shows a relatively high species diversity. These species can be considered pseudocryptic species, meaning that (subtle) morphological differences may be found when studied in detail, as was done for two new Neotropical species: Lactifluus hallingii and L. domingensis. The identity of the true $L$. deceptivus is revealed. However, more welldocumented collections are needed for most species in this complex, of which many are known from only one or two collections. Now that it was shown that L. deceptivus s. lat. Represents several morphologically similar species, the number of well-documented collections will hopefully rise substantially, ameliorating the possibility of fully resolving this species complex.

\section{Acknowledgements}

The Panamanian Environmental Ministry (MiAmbiente) is thanked for issuing permits for collection (SE/PH-4-18) and export (SEX/H-2-18) of fungi, Orlando Cáceres, Tina Hofmann and Manlio Cuevas are thanked for logistic support in Panama. Meike Piepenbring is thanked for establishing contact to the

Panamanian University and Felix Hampe for taking field photographs of Panamanian collections. Karen Hughes and Ron Petersen are acknowledged for organization of the field trip in Smokey Mountains (USA).

\section{Adherence to national and international regulations}

We confirm adherence to any pertinent national or international legislation or regulations that apply to the transfer of living biotic materials used in the study between countries.

\section{Authors' contributions}

LD gathered collections/sequences to constitute the final dataset, performed the molecular analysis, performed a microscopical study, made the descriptions for the new species and the microscopic plates, and wrote the manuscript. GD performed part of the microscopical study and part of the molecular lab work. SDW authored the masters dissertation that did a first exploration of $L$. sect. Albati, which provided an initial dataset and revealed that $L$. deceptivus represented a species complex. CA collected the specimens from Dominican Republic and made the macroscopical 
description of $L$. domingensis. EDC was the supervisor of the masters dissertation of SDW, and is responsible for gathering/generating the data of this initial dataset. RDL performed part of the molecular lab work. RH made several collections of $L$. hallingii and contributed to the macroscopical description. CM collected the type collection of L. hallingii and contributed to the macroscopical description. JN organised the Illumina run in which the types of L. deceptivus, L. tomentoso-marginatus and L. mordax were sequenced. AV is the promotor of the first author, as well as the promotor of the masters dissertation of SDW, performed part of the microscopical study and made the line drawings of pileipellis and stipitipellis. All authors read and approved the final manuscript.

\section{Funding}

L. Delgat (grant BOFDOC2015007001) and E. De Crop (grants B/13485/01 and BOF-PDO-2017-001201) are funded by scholarships of the Special Research Fund. R. Halling was funded by grants from the National Science Foundation (USA) and the National Geographic Society.

\section{Availability of data and materials}

All data generated or analysed during this study are included in this published article [and its supplementary information files].

\section{Ethics approval and consent to participate}

Not applicable.

\section{Consent for publication}

Not applicable.

\section{Competing interests}

The authors declare that they have no competing interests.

\section{Author details}

${ }^{1}$ Department of Biology, Research group Mycology, Ghent University, K.L. Ledeganckstraat 35, 9000 Ghent, Belgium. ${ }^{2}$ Via Cappuccini 78/8, I-33170 Pordenone, Italy. ${ }^{3}$ National Botanical Garden of Santo Domingo (JBSD), Santo Domingo, Dominican Republic. ${ }^{4}$ Institute of Systematic Botany, The New York Botanical Garden, 2900 Southern Blvd, Bronx, NY 10458-5126, USA ${ }^{5}$ Faculty of Biology, Systematic Botany and Mycology, University of Marburg, Karl-von-Frisch-Straße 8, 35043 Marburg, Germany. ${ }^{6}$ Naturalis Biodiversity Center, P.O. Box 9517, 2300RA Leiden, The Netherlands.

Received: 29 May 2019 Accepted: 27 August 2019

Published online: 18 September 2019

\section{References}

Altschul SF, Madden TL, Schäffer AA, Zhang J, Zhang Z, Miller W, Lipman DJ (1997) Gapped BLAST and PSI-BLAST: a new generation of protein database search programs. Nucleic Acids Research 25:3389-3402

Buyck B, Hofstetter V, Eberhardt U, Verbeken A, Kauff F (2008) Walking the thin line between Russula and Lactarius: the dilemma of Russula subsect. Ochricompactae. Fungal Diversity 28:15-40

De Crop E (2016) Global phylogeny and evolutionary history of the genus Lactifluus. PhD, Ghent University, Ghent, Belgium

De Crop E, Nuytinck J, Van de Putte K, Lecomte M, Eberhardt U, Verbeken A (2014) Lactifluus piperatus (Russulales, Basidiomycota) and allied species in Western Europe and a preliminary overview of the group worldwide. Mycological Progress 13:493-511

De Crop E, Nuytinck J, Van de Putte K, Wisitrassameewong K, Hackel J, Stubbe D, Hyde KD, Roy M, Halling RE, Moreau PA et al (2017) A multi-gene phylogeny of Lactifluus (Basidiomycota, Russulales) translated into a new infrageneric classification of the genus. Persoonia 38:58-80

De Lange R, De Crop E, Delgat L, Tibuhwa D, Baribwegure D, Verbeken A (2018) Lactifluus kigomaensis and L. subkigomaensis: two look-alikes in Tanzania. Mycoscience 59:371-378

Delgat L, De Crop E, Njouonkou AL, Verbeken A (2017) Lactifluus persicinus sp. nov. from the gallery forests of West Cameroon. Mycotaxon 132:471-483

Edgar RC (2016) UNOISE2: improved error-correction for Illumina 165 and ITS amplicon sequencing. BioRxiv:081257. https://doi.org/10.1101/081257

Edgar RC, Flyvbjerg H (2015) Error filtering, pair assembly and error correction for next-generation sequencing reads. Bioinformatics 31:3476-3482
Edgar RC, Haas BJ, Clemente JC, Quince C, Knight R (2011) UCHIME improves sensitivity and speed of chimera detection. Bioinformatics 27:2194-2200

Forin N, Nigris S, Voyron S, Girlanda M, Vizzini A, Casadoro G, Baldan B (2018) Next generation sequencing of ancient fungal specimens: the case of the Saccardo mycological herbarium. Frontiers in Ecology and Evolution 6:19

Gardes M, Bruns TD (1993) ITS primers with enhanced specificity for Basidiomycetes - application to the identification of mycorrhizae and rusts. Molecular Ecology 2:113-118

Hesler LR, Smith AH (1979) North American species of Lactarius, vol 841. University of Michigan Press, Ann Arbor

Katoh K, Toh H (2008) Recent developments in the MAFFT multiple sequence alignment program. Briefings in Bioinformatics 9:286-298

Kornerup A, Wanscher JH (1978) Methuen handbook of colour. Methuen, London

Lanfear R, Frandsen PB, Wright AM, Senfeld T, Calcott B (2017) PartitionFinder 2: new methods for selecting partitioned models of evolution for molecular and morphological phylogenetic analyses. Molecular Biology and Evolution 34:772-773

Le HT, Nuytinck J, Verbeken A, Lumyong S, Desjardin DE (2007a) Lactarius in northern Thailand: 1. Lactarius subgenus Piperites. Fungal Diversity 24:173-224

Le HT, Verbeken A, Nuytinck J, Lumyong S, Desjardin DE (2007b) Lactarius in northern Thailand: 3. Lactarius subgenus Lactoriopsis. Mycotaxon 102:281-291

Liu YJJ, Whelen S, Benjamin DH (1999) Phylogenetic relationships among ascomycetes: evidence from an RNA polymerase II subunit. Molecular Biology and Evolution 16:1799-1808

Magoc T, Salzberg SL (2011) FLASH: fast length adjustment of short reads to improve genome assemblies. Bioinformatics 27(21):2957-2963.

Martin M (2011) Cutadapt removes adapter sequences from high-throughput sequencing reads. EMBnet journal 17:10-12

Matheny PB (2005) Improving phylogenetic inference of mushrooms with RPB1 and RPB2 nucleotide sequences (Inocybe; Agaricales). Molecular Phylogenetics and Evolution 35:1-20

Miller MA, Pfeiffer W, Schwartz T (2010) Creating the CIPRES science gateway for inference of large phylogenetic trees. In: Proceedings of the gateway computing environments workshop (GCE), pp 1-8

Montoya L, Bandala VM (2005) Revision of Lactarius from Mexico. Additional new records. Persoonia-Molecular Phylogeny and Evolution of Fungi 18:471-483

Murrill WA (1939) Some Florida gill-fungi. Journal of the Elisha Mitchell Scientific Society 55:361-372

Murrill WA (1941) More Florida Novelties. Mycologia 33:434-448

Nuytinck J, Verbeken A (2003) Lactarius sanguifluus versus Lactarius vinosus molecular and morphological analyses. Mycological Progress 2:227-234

Peck CH (1885) New species of Lactarius. Annual Report New York State Museum 38:111-133

Schmieder R, Edwards R (2011) Quality control and preprocessing of metagenomic datasets. Bioinformatics 27:863-864

Stamatakis A (2014) RAxML version 8: a tool for phylogenetic analysis and postanalysis of large phylogenies. Bioinformatics 30:1312-1313

Stamatakis A, Hoover P, Rougemont J (2008) A rapid bootstrap algorithm for the RAxML web servers. Systematic Biology 57:758-771

Stubbe D (2012) Systematics and phylogeny of Lactarius subgenus Plinthogalus sensu lato. PhD, Ghent University, Ghent, Belgium

Stubbe D, Nuytinck J, Verbeken A (2010) Critical assessment of the Lactarius gerardii species complex (Russulales). Fungal Biology 114:271-283

Tamura K, Stecher G, Peterson D, Filipski A, Kumar S (2013) MEGA6: molecular evolutionary genetics analysis version 6.0. Molecular Biology and Evolution 30:2725-2729

Tedersoo L, Mett M, Ishida TA, Bahram M (2013) Phylogenetic relationships among host plants explain differences in fungal species richness and community composition in ectomycorrhizal symbiosis. New Phytologist 199:822-831

Tel-Zur N, Abbo S, Myslabodski D, Mizrahi Y (1999) Modified CTAB procedure for DNA isolation from epiphytic cacti of the genera Hylocereus and Selenicereus (Cactaceae). Plant Molecular Biology Reporter 17:249-254

Thiers HD (1957) The agaric flora of Texas. I. New species of Agarics and Boletes. Mycologia 49:707-722

Van de Putte K (2012) Hidden diversity exposed: a case study of Lactifluus volemus sensu lato. PhD, Ghent University, Ghent, Belgium

Van de Putte K, Nuytinck J, De Crop E, Verbeken A (2016) Lactifluus volemus in Europe: three species in one - revealed by a multilocus 
genealogical approach, Bayesian species delimitation and morphology. Fungal Biology 120:1-25

Van de Putte K, Nuytinck J, Stubbe D, Huyen TL, Verbeken A (2010) Lactarius volemus sensu lato (Russulales) from northern Thailand: morphological and phylogenetic species concepts explored. Fungal Diversity 45:99-130

Wen HA, Ying JZ (2005) Studies on the genus Lactarius from China II. Two new taxa from Guizhou. Mycosystema 24:155-158

White TJ, Bruns T, Lee S, Taylor JW (1990) Amplification and direct sequencing of fungal ribosomal RNA genes for phylogenetics. In: Innis MA, Gelfand DH, Sninsky JJ, White TJ (eds) PCR protocols: a guide to methods and applications. Academic Press, New York, pp 315-322

\section{Publisher's Note}

Springer Nature remains neutral with regard to jurisdictional claims in published maps and institutional affiliations.

Ready to submit your research? Choose BMC and benefit from:

- fast, convenient online submission

- thorough peer review by experienced researchers in your field

- rapid publication on acceptance

- support for research data, including large and complex data types

- gold Open Access which fosters wider collaboration and increased citations

- maximum visibility for your research: over $100 \mathrm{M}$ website views per year

At BMC, research is always in progress.

Learn more biomedcentral.com/submissions 